\title{
KILKA UWAG O KONTRASTYWNEJ ANALIZIE STYLU
}

\author{
IZABELA PROKOP
}

\begin{abstract}
A few remarks on the contrastive analysis of style
The phenomenon of style, analysed from different points of view, has been presented in this article. On the one hand, connections between stylistics and pragmalinguistics with the psychological profile of the sender have been indicated. Janusz Reykowski's distinction of the five levels of centralisation, included in his publications, has turned out to be most useful in the pragmalinguistic analysis while describing the locutionary act, including the stylistic phenomena. On the other hand, though, a question about the possibility and limits of the reflection of style in translation has been asked, using the text example in a German-Polish pair, and working out the criteria of evaluation. In the conclusion of the article the author is postulating the formation of a German-Polish contrastive stylistics.
\end{abstract}

Key words: contrastive stylistics, language style, denotative equivalence

Zagadnienie możliwości ergonomicznego opisu stylu utworów literackich w poszczególnych epokach oraz stylu poszczególnych twórców literatury nurtuje już od dawna zarówno literaturoznawców, jak i językoznawców. Od lat 60-tych XX wieku, kiedy zaczęły powstawać w Polsce korpusy tekstowe, zainteresowanie stylistyką objęło również badania stylów funkcjonalnych, występujących w autentycznych sytuacjach komunikacyjnych życia codziennego. Obecnie, gdy mamy do dyspozycji zdigitalizowane korpusy $\mathrm{w}$ wielu językach, badania nad językiem mówionym nie zawsze wiążą się z tak dużym nakładem czasu i środków jak w minionym czasie, mogą więc zostać znacznie zintensyfikowane. Oprócz czytelnych, możliwie kompletnych transkryptów potrzebujemy obecnie narzędzi badawczych w postaci modeli wielowarstwowej analizy zarejestrowanych wypowiedzi. Podczas gdy słowotwórstwo, morfologia, morfoskładnia i lingwistyka tekstu dysponują wieloma modelami analizy, to stylistyka zdaje się nadal stać na samej granicy dostępności badawczej. 
W tradycji filologicznej stylistyka zaliczana była przeważnie do zakresu badawczego literaturoznawstwa. Jednak wraz z rozwojem studiów kontrastywnych od końca lat 60-tych XX wieku także językoznawcy podjęli próby opisu elementów stylu w trakcie badań nad ekwiwalencją tłumaczeniową tekstów literackich i użytkowych. Styl ustnych wypowiedzi, realizowanych w autentycznych sytuacjach komunikacyjnych nie doczekał się jeszcze zbyt wielu opracowań, tym bardziej więc istnieje pilna potrzeba uzupełnienia tego deficytu badawczego. Wielu autorów uważa stylistykę za subdyscyplinę naukową, usytuowaną pomiędzy nurtem badań literaturoznawczych i językoznawczych. W licznych pracach autorów niemieckich (por. np. Fleischer, Michel i Starke, 1993: 13 ff) stylistyka sytuuje się w obrębie lingwistyki tekstu, ale też podkreśla się jednoznacznie fakt, iż nauka o stylu wykracza daleko poza naukę o tekście, podobnie jak teoria aktów mownych, analiza dyskursu czy teorie translatorskie. Wymienione subdyscypliny językoznawstwa jednak łączy ze stylistyką nie tylko cecha interdyscyplinarności, lecz również różnorakie zależności, wynikające $\mathrm{z}$ badania tego samego fenomenu, to jest znaku językowego w trakcie jego konkretnego użycia.

Znaczenie badania zależności między stylistyką, lingwistyką tekstu i pragmalingwistyką podkreślali już jakiś czas temu Urszula Żydek-Bednarczuk (2005) oraz Stanisław Gajda (2008: 145), obecnie zaś, w obliczu etablowania antropocentrycznej teorii języków naturalnych, badanie tych zależności jest już koniecznością. Podczas kiedy tradycyjnie pojmowana stylistyka badała styl utworu, antropocentryczne podejście do językoznawstwa zmienia ten punkt widzenia i nakazuje badania nad stylem wypowiadania się konkretnej jednostki w ramach badania języków rzeczywistych. Pragmalingwistyka antropocentryczna stara się wyjaśnić mechanizmy konstruowania wypowiedzi (realizowania aktów mownych) oraz zbadać ich wielorakie uwarunkowania.

Od niemal sześćdziesięciu lat w licznych pracach językoznawczych cytowane są poglądy nestora pragmalingwistyki, Johna Austine'a, zawarte w pozycji How to do things with words (w języku angielskim 1962 oraz thumaczenie na język niemiecki 1972). Przyjrzyjmy się składnikom aktu mownego lub też aktom cząstkowym:

- akt fonetyczny stanowi produkcję dźwięku ( w komunikacji ustnej);

- akt fatyczny sytuuje te dźwięki w określoną postać, z określonym słownictwem oraz w określonych konstrukcjach gramatycznych;

- akt retyczny przynosi określenie znaczenia;

- akt illokucyjny ujmuje dźwięki w określony sposób wyrażenia się, to jest na przykład w informowanie się, pytanie, wydanie rozkazu;

- akt perlokucyjny znajduje się po stronie odbiorcy i określa sposób oddziaływania na jego myśli, uczucia i działanie.

W powyższym poglądowym przedstawieniu struktury aktu mownego stylistyka wydaje się być mało wyeksponowana. W pracach Johna Searle'a akt mowny rozumiany jest jako najmniejsza jednostka komunikacji, a w skrajnym przypadku posłu- 
giwania się jedynie bezpośrednimi aktami mowy (mówienia tego, co się myśli) akt mowny można określić poprzez zdanie, a w czasie jego wypowiadania realizowane są jednocześnie

- akt wyrażania;

- akt propozycjonalny;

- akt illokucyjny i

- akt perlokucyjny.

Aby ukazać zależności pomiędzy pragmalingwistyką a stylistyką, a dokładniej - ukazać mechanizmy doboru środków stylistycznych, wychodzimy z następującego założenia:

Akty mowne posiadają strukturę złożoną, a ich części składowe to 1) illokucja, 2) zawartość propozycjonalna, 3) lokucja oraz 4) perlokucja.

Składniki aktu mownego od 1-3 występują po stronie nadawcy, a perlokucja po stronie odbiorcy aktu. Illokucja, propozycja, lokucja oraz perlokucja rozdzielone są więc zarówno w przestrzeni, jak i w czasie i nie występują jednocześnie.

Illokucja, niezbędna do zaistnienia wypowiedzi, powstaje w umyśle nadawcy i wyprzedza pozostałe składniki aktu mownego. Jeśli wprowadzimy do analizy pragmalingwistycznej pojęcie nastawienia (Prokop, 2016: 50), to illokucję możemy rozpatrywać na dwu płaszczyznach:

- na płaszczyźnie wewnętrznej i

- płaszczyźnie zewnętrznej.

Płaszczyzna wewnętrzna, znajdująca się w psychice nadawcy aktu, jest obecna stale, również przed podjęciem jakiegokolwiek działania werbalnego. Ponieważ ściśle się ona łączy z nastawieniem o ustopniowaniu I-V, to znaczy od skrajnie egocentrycznego do skrajnie allocentrycznego, również repertuar środków językowych, w tym stylistycznych, jest indywidualnie zróżnicowany i przenika wszystkie wypowiedzi danej jednostki. Tak realizowaną illokucję możemy więc nazwać illokucją globalną. Płaszczyzna zewnętrzna wobec mówiącego indywiduum jest płaszczyzną, na której mamy do czynienia z illokucją lokalną, odnoszącą się do konkretnych spraw w konkretnych interakcjach, w które wchodzi jednostka.

$\mathrm{W}$ tabeli poniżej przedstawiamy zróżnicowanie illokucji globalnej z zależności od stopnia centracji (poziomu) od I-V.

W aspekcie stylistyki rozróżnienie pięciu typów postaw i odpowiadających im pięciu poziomów illokucji globalnej pozwoli nam w przyszłości na badanie idiolektów pojedynczych osób w autentycznych sytuacjach komunikacyjnych. Już po przebadaniu małych próbek materiału empirycznego możemy zauważyć prawidłowości w stosowaniu środków stylistycznych u osób, reprezentujących różne poziomy centracji, nawet niezależnie od zawartości propozycjonalnej aktów mownych. Fenomeny stylistyczne zdają się tutaj mieć jedno ze źródeł. Pewne cechy stylu przenikają wszystkie zachowania komunikacyjne jednostki i nawet wydają się być niezależne od parametrów sytuacji komunikacyjnej. 
Tabela 1. Zróżnicowanie illokucji globalnej ze względu na poziom centracji

\begin{tabular}{|c|c|c|}
\hline $\begin{array}{l}\text { Poziom } \\
\text { centracji }\end{array}$ & Illokucja globalna & Komentarz \\
\hline $\begin{array}{l}\text { Pozom I, } \\
\text { postawa I }\end{array}$ & $\begin{array}{l}\text { Chcę zaznaczyć swoją obecność. } \\
\text { Chcę zabezpieczyć moje interesy. } \\
\text { Chcę uzyskać potwierdzenie mojej wysokiej wartości. } \\
\text { W działaniach chcę kierować się jedynie zasadą } \\
\text { pozyskiwania maksymalnej korzyści. } \\
\text { Chcę, aby moje sprawy były traktowane zawsze jako } \\
\text { najważniejsze, nie ma spraw innych niż moje. } \\
\text { Chcę pokazać innym, że nie są tak kompetentni jak ja. } \\
\text { Żądam, żeby bezwyjątkowo wszyscy uznawali moje } \\
\text { prawo do pierwszeństwa we wszystkich sprawach. }\end{array}$ & $\begin{array}{l}\text { Niezależnie od illokucji lokalnej } \\
\text { osoba o postawie I zaznacza swo- } \\
\text { ją obecność poprzez stałe komen- } \\
\text { towanie i ocenianie zachowań } \\
\text { innych oraz otaczających stanów } \\
\text { rzeczy. Ocena ta jest z reguły } \\
\text { negatywna. Konflikty częste. }\end{array}$ \\
\hline $\begin{array}{l}\text { Poziom II, } \\
\text { postawa II }\end{array}$ & $\begin{array}{l}\text { Chcę zaznaczyć swoją obecność. } \\
\text { Chcę zabezpieczyć moje interesy. } \\
\text { Chcę uzyskać potwierdzenie mojej wysokiej wartości. } \\
\text { Chcę, aby moje sprawy były traktowane jako waż- } \\
\text { niejsze od spraw innych ludzi. } \\
\text { Wymagam, aby respektowano moje prawa. }\end{array}$ & $\begin{array}{l}\text { Osoba o postawie II zaznacza } \\
\text { swoją obecność jak wyżej. } \\
\text { Konflikty częste. }\end{array}$ \\
\hline $\begin{array}{l}\text { Poziom III, } \\
\text { postawa III }\end{array}$ & $\begin{array}{l}\text { Chcę, aby niektóre moje sprawy były traktowane jako } \\
\text { ważniejsze od niektórych spraw innych ludzi. }\end{array}$ & $\begin{array}{l}\text { W niektórych sytuacjach osoba } \\
\text { o postawie III współdziała z inny- } \\
\text { mi i dostrzega ich interesy. W roz- } \\
\text { mowach werbalizowane są pro- } \\
\text { blemy innych i występują próby } \\
\text { negocjacji. } \\
\text { Występują próby rozwiązywania } \\
\text { konfliktów. }\end{array}$ \\
\hline $\begin{array}{l}\text { Poziom IV, } \\
\text { postawa IV }\end{array}$ & $\begin{array}{l}\text { Chcę współdziałać z innymi, chcę, aby inni respek- } \\
\text { towali moje prawa, gdy ja respektuję ich prawa. }\end{array}$ & $\begin{array}{l}\text { Rozbudowane sekwencje negocja- } \\
\text { cyjne. Logiczna argumentacja. }\end{array}$ \\
\hline $\begin{array}{l}\text { Poziom V, } \\
\text { postawa V }\end{array}$ & $\begin{array}{l}\text { Chcę współdziałać z innymi na zasadach równości. } \\
\text { Chcę uwzględniać własne interesy na równi z intere- } \\
\text { sami innych. } \\
\text { Chcę kształtować interakcje przyjazne dla mnie i dla } \\
\text { innych. } \\
\text { Chcę nieść pomoc, jeśli ktoś tego potrzebuje. }\end{array}$ & $\begin{array}{l}\text { Osoby o postawie allocentrycznej } \\
\text { okazują współczucie i autentyczne } \\
\text { zainteresowanie sprawami innych. }\end{array}$ \\
\hline
\end{tabular}

Źródło: Prokop, I. 2016. Pragmalingwistyka antropocentryczna. Poznań: Wydawnictwo Naukowe UAM. 51-52.

Illokucja lokalna występuje w aktach mownych, za pomocą których jednostka działa $w$ interakcjach i realizuje różne zadania, zaspokajające jej potrzeby materialne i niematerialne, a środki językowe, w tym cechy stylistyczne realizowanych aktów mownych w mniejszym stopniu zależne są od osobowości nadawcy, tj. opisanego wyżej nastawienia, a bardziej od parametrów sytuacji komunikacyjnej, a zwłaszcza od typu relacji między nadawcą a odbiorcą.

Zastanówmy się obecnie, co wyzwala zaistnienie zamiaru komunikacyjnego.

Zamiar komunikacyjny wynika $\mathrm{z}$ dwojakich przesłanek:

- Po pierwsze, $z$ konkretnych potrzeb jednostki, a realizacja zamierzonego aktu mownego jest środkiem do zaspokojenia tych potrzeb, na przykład zaistnienie 
deficytu wiedzy u nadawcy jest impulsem do zrealizowania erotetycznego aktu mownego; nadmiar dobrych uczuć względem interlokutora uzewnętrznia się poprzez benefaktywny akt mowny; gdy nadawca odczuwa brak konkretnego przedmiotu, na przykład długopisu, gazety, kartki papieru czy biletu tramwajowego, kieruje do rozmówcy akt mowny z grupy dyrektywów itd. W tej grupie mamy do czynienia $\mathrm{z}$ wieloma najróżniejszymi sytuacjami, takimi jak załatwianie spraw w urzędach, regulowanie należności w banku, dokonywanie zakupów i korzystanie z usług lekarskich, rzemieślniczych i innych;

- Po drugie, akt komunikacyjny wynika z zewnętrznych uwarunkowań: jednostka podejmuje się realizacji aktu mownego, wykonując dyrektywę, np. wyłoniony przez grupę kilkorga uczestników projektu uczeń referuje na forum klasy wyniki pracy grupy; pracownik zdaje sprawę z wykonania zadań zawodowych swojego działu przed przełożonym; polityk w czasie kampanii wyborczej przemawia do mieszkańców miasta, by przekonać ich do swego programu i uzyskać mandat poselski lub stanowisko.

Obok illokucji każdy akt mowny zawiera treść, czyli zawartość propozycjonalną. Jest to oczywiście jak najbardziej zrozumiałe, że występują one jednocześnie: w naszym pierwszym przypadku, gdy nadawca czegoś potrzebuje, owo coś jest właśnie propozycją. Engel (2000: 48) wskazuje na trudności w rozdzieleniu illokucji i propozycji. Trudności tych jest wiele, gdybyśmy bowiem rozpatrywali sytuację braku np. jogurtu w lodówce, to mamy tu różne możliwości interpretacji. Zakładając, że większość $\mathrm{z}$ nas nie prowadzi ewidencji towarów, a więc mogą się one skończyć niespodziewanie, wystąpić może sytuacja, gdy zaglądamy do lodówki, szukamy przez chwilę, nie znajdujemy jogurtu, więc postanawiamy niezwłocznie bądź też przy najbliższej okazji, na przykład jutro, pójść do sklepu i zrobić zakupy. Najpierw zaistniała więc propozycja, a następnie illokucja. Na przykładzie tej samej sytuacji możemy mieć do czynienia z kolejnością odwrotną: postanawiamy pójść do sklepu, by zrobić zakupy (illokucja), a następnie zaglądamy do lodówki i szafki kuchennej i sporządzamy w pamięci lub na kartce spis towarów do nabycia (propozycja).

W naszym drugim przypadku nadawca otrzymuje dyrektywę, jego zadaniem jest, na przykład, wygłoszenie przemówienia w zastępstwie nieobecnego zwierzchnika. $\mathrm{W}$ tym przypadku również mamy do czynienia $\mathrm{z}$ dość wyraźnym rozdzieleniem illokucji i propozycji, w tym wypadku jednak propozycja zaistniała jako pierwsza przybyli goście z określonej okazji, których należy powitać. Nadawca dokonuje wyboru odpowiedniej formuły powitania, na przykład wahając się między stwierdzeniem, że goście mieli miłą podróż i że podoba im się nasze miasto a dyrektywnym aktem mownym, tj. życzeniem, by bawili się dobrze i skorzystali z uroków naszego regionu. Zagadnienie relacji między illokucją a propozycją odkładamy więc niniejszym do dalszych badań. 


\section{Lokucja}

W obu powyższych przypadkach jednostka realizuje akt lokucji, zabiera głos, musi więc dokonać wyboru środków językowych do realizacji zaplanowanego aktu mownego. Zakładamy, w myśl antropocentrycznej teorii, że zarówno wokabularz, jak i środki stylistyczne stanowią składniki idiolektu danej osoby. O ich użyciu w konkretnej konstelacji decyduje osoba mówiąca. Akt lokucji jest więc mniej lub bardziej dynamicznie przebiegającym procesem selekcji środków językowych. Proces ten przebiega często bezrefleksyjnie, często też towarzyszy mu namysł i rozważania o doborze słownictwa lub struktur syntaktycznych wyrażane czasem głośno, dobór środków stylistycznych jest czasami czynnością kolektywną. W przypadku pisarzy, dziennikarzy, naukowców, pamiętnikarzy czy innych osób parających się tworzeniem tekstów przebieg procesu lokucji możemy prześledzić na podstawie notatek czy brudnopisów utworów.

Jeśli chodzi o znaczenie postawy (nastawienia) dla stylistycznej warstwy ustnej lub pisemnej wypowiedzi, to jest ono niewątpliwe. W naszych badaniach nad autonomizacją studentów w protokołach obserwacji lekcji stwierdziliśmy wśród poddanych badaniu nauczycieli obecność przejawów dwu skrajnych postaw: egocentrycznej i allocentrycznej, które można było zidentyfikować, obserwując użycie zaimka osobowego ja.

W naszkicowanym powyżej przypadku pierwszym mamy do czynienia w większości z sytuacjami z życia codziennego oraz z interlokutorami, którzy są członkami rodziny lub grupy przyjaciół i znajomych, a także sprzedawcami, usługodawcami, urzędnikami lub też całkiem obcymi osobami, przechodniami na ulicy lub pasażerami środków komunikacji miejskiej, których często pytamy o drogę. W sytuacjach tych brakuje publiczności, mają one charakter prywatny, wszystkie osoby obecne są zarazem uczestnikami aktów komunikacyjnych. Dobór środków językowych jest podporządkowany naczelnemu celowi takich interakcji: możliwie sprawnemu przekazaniu niezbędnych informacji i optymalnemu osiągnięciu porozumienia. Zawartość propozycjonalną stanowią zakupy, naprawy, usługi i inne potoczne sprawy. Akty mowne są przeważnie realizowane całkowicie spontanicznie, poprzedzone przygotowaniem jedynie $\mathrm{w}$ zakresie zasięgnięcia niezbędnej informacji, np. o numerach telefonu lub adresach firm czy sklepów, o kosztach itd. Brak przygotowania większych jednostek tekstowych do wygłoszenia jest usprawiedliwiony faktem, że przecież w toku interakcji face-to-face następuje na bieżąco korygowanie ewentualnych błędnych przekonań. Wśród środków językowych znajdują się tu często terminy specjalistyczne wraz z towarzyszącą im strukturą wypowiedzi, bez trudu jednak możemy rozpoznać nastawienie nadawcy i cechy jej indywidualnej odmiany języka.

$\mathrm{W}$ przypadku drugim mamy do czynienia z aktami mownymi, realizowanymi wobec (często licznej) publiczności. Osoba mówiąca/pisząca przy doborze środków językowych więc $\mathrm{w}$ większym stopniu niż $\mathrm{w}$ przypadku pierwszym uwzględnia 
odbiorców, np. ich możliwości percepcji, znajomość języków obcych, możliwości zrozumienia długich okresów zdaniowych, humoru słownego, gry słów czy aluzji. Teksty z tej grupy mają formę tekstów pisanych, lub też pierwotnie przygotowanych na piśmie, a potem wtórnie przeniesionych do komunikacji ustnej poprzez odczytanie.

Do wybranej illokucji i zawartości propozycjonalnej aktu mownego należy teraz dopasować warstwę stylistyczną - na przykład wybrać rejestr języka potocznego lub nawet niedbałego potocznego lub też sięgnąc do stylu górnolotnego, nawet zabarwionego patosem, czy starać się wyrażać w stylu urzędowym. W wielu wypowiedziach warstwa stylistyczna nie jest jednolita, obserwujemy poruszanie się nadawcy po dwu lub więcej warstwach. Z warstwą stylistyczną ściśle związany jest dobór konkretnych wyrazów, a przy ich doborze nadawca czerpie z posiadanego zasobu słownictwa, skromnego lub bardziej obszernego. Wybór warstwy stylistycznej, dobór słownictwa, uszeregowanie poszczególnych wyrazów w struktury zdaniowe, a następnie wyartykułowanie wypowiedzi bądź jej napisanie to ogólnie lokucja. W każdym razie możemy przyjąć za pewnik, że wybór rejestru stylistycznego poprzedza wybór jednostek leksykalnych, wyrazy są dobierane do warstwy stylistycznej.

Postulaty badawcze Yngve'go i Gruczy, przytoczone w Pragmalingwistyce antropocentrycznej (Prokop, 2016), skierują obecnie badania nad językiem mówionym i nad językami specjalistycznymi na nowe tory. Również teksty literackie i publicystyczne stanowią doskonały materiał do zilustrowania modelu badania stylu. Ogromna liczba tekstów, tłumaczonych każdego dnia oraz konieczność kształcenia tłumaczy oraz specjalistów, znających języki obce i potrafiących sprawnie kształtować różnorodne teksty każe nam się zastanowić nad zagadnieniem stylu w przekładzie, a więc $w$ niniejszych rozważaniach $w$ centrum zainteresowania umieszczamy badanie ekwiwalencji thumaczeniowej w zakresie stylistyki. Znaczenie kontrastywnego opisu stylistycznego dla translatoryki trudno dziś przecenić. Problematyka przetłumaczalności stylistycznej wynika z tego, że systemy wartości konotatywnych, kształtujące styl, nie odpowiadają sobie w różnych językach jak 1:1 (Koller, 1992: 242).

Spośród różnych rozważań na ten temat wymieńmy choćby niektóre zakresy tematyczne spośród licznych badań nad stylem thumaczeń utworów literackich. Dobór środków językowych, jakimi posłużyli się tłumacze, których przekłady składają się na serię translatorską, to przedmiot badania nader aktualny, gdy na rynku wydawniczym koegzystują różne przekłady. Zarek (1991: 11 i nast.) zauważa w swoich analizach przekładów czeskiego poety Jaroslava Seiferta, że w badanych tekstach dwóch thumaczy - Andrzeja Piotrowskiego i Józefa Waczkowa można zaobserwować różnice w zakresie rejestru językowego - wyrazy z warstwy neutralnej zastąpiono wyrażeniami z języka potocznego, np. prowadziła $(J W)$ zamiast wiodła $(A P)$, zwality się $(J W)$ zamiast runęty $(A P)$, Autor wskazuje też na różnice w zakresie grafostylistyki obu tłumaczeń: na przykład wyraz Dekalog/dekalog pisany jest raz 
z małej, a raz z dużej litery. Szczegółowo tematyką grafostylistyki w ramach niemiecko-polskiego przekładoznawstwa zajmuje się Joanna Kubaszczyk (2016). Pominąwszy zagadnienie serii translatorskich, wielu autorów stwierdza, że poziom stylistyczny przekładów często nie wytrzymuje krytyki, jak na przykład w zakresie archaizacji słownictwa, co zauważa Barbara Musialik (1991: 126-128). W poezji Belli Achmaduliny np. wiele archaizmów zastąpiono w przekładzie wyrazami neutralnymi stylistycznie, a zjawisko to autorka ocenia jako stylistyczne zubożenie thumaczenia w porównaniu z oryginałem. Nasze własne badanie przekładu Trylogii Henryka Sienkiewicza na język niemiecki wykazało zjawisko jeszcze dalej idącej ingerencji w tekst: mianowicie wszelkie jednostki syntaktyczne, a nawet całe akapity, w których występowały archaizmy, zostały w thumaczeniu pominięte, nieraz z wyraźnym uszczerbkiem dla przebiegu akcji (Prokop, 2011). Należąca również do sfery lokucji składnia w przekładzie wymaga często wirtuozerii tłumacza, czasem thumacz wykorzystuje reguły składniowe w sposób twórczy (Pisarkowa, 1998: 101-102).

Oddajmy jeszcze głos autorom, zajmującym się krytyką przekładu: „Poziom stylistyczny obejmuje rodzaj i sposób użycia środków stylistycznych w oryginale oraz ich realizację w przekładzie. Na tym poziomie o wiele trudniej niż na poziomie leksykalno-składniowym o obiektywne kryteria oceny. Im bogatszy jest tekst pod względem artystycznym, im większą rolę odgrywa forma, tym większa może być rozbieżność sądów i ocen“ (Adamczyk-Garbowska, 1988: 33). Pogląd ten jest powszechny. Sfera stylistyczna to różne fenomeny, na przykład nasycenie tekstu wyjściowego frazeologizmami stwarza tłumaczowi trudności, więc przekład jest czasem w tym aspekcie zbliżony do oryginału lub w sposób wyraźny od niego odbiegający, jak to wskazują Jerzy Paszek i Grażyna Wilk (1991: 22), analizując tłumaczenia utworów Puszkina na język polski. Maria Krysztofiak (1998: 172), podziwiając artyzm autorów - braci Grimm dostrzega, że na uniwersalne struktury baśni ludowych nakładają oni swoje własne ,strategie uniwersalizacji świata przedstawionego". Te wybrane poglądy tłumaczy i badaczy stylistyki w przekładzie ukazują nam szerokie spektrum zagadnień, jakie należy uwzględnić w modelu ekwiwalencji konotatywnej. W świetle powyższych problemów próba stworzenia modelu do opisu translatorskiego w zakresie stylu jest w pełni uzasadniona.

Poniżej przedstawiam próbę ujęcia ekwiwalencji konotatywnej w ramy ilościowe, co może się okazać przydatne $\mathrm{w}$ analizach translatorskich, wykonywanych w pracach licencjackich i magisterskich na studiach neofilologicznych. Materiałem do rozważań jest esej autorstwa Klausa Staecka pt. Jeder zweite Deutsche hat Übergewicht/Co drugi Niemiec ma nadwage (thumaczenie: Izabela Prokop, 1992). Przytaczam tu jedynie fragment (ze strony 259) dość obszernego tekstu, aby umożliwić czytelnikowi zapoznanie się ze stylem autora, zaś przykłady konkretnych rozwiązań translatorskich pochodzą częściowo również z innych części tegoż tekstu. 
Klaus Staeck „Jeder zweite Deutsche hat Übergewicht“

Seit nunmehr vier Wochen vollzieht sich jeden Tag dasselbe: heute abend setze ich mich hin und schreibe es einfach runter. Deutschland - als hätte man nicht vierzig Jahre darauf gewartet, einmal mit diesem Land abzurechnen, einmal alles schwarz auf weiß niederzuschreiben, wenn man schon danach gefragt wird. Doch jeder Anfang wird verdorben durch neue Zweifel. Es darf nicht zu pathetisch werden, das wäre zu deutsch. Nicht sentimental, auch deutsch. Nicht heroisch, nicht stur, vor allem nicht so gründlich, nicht zu kleinkariert, nicht so treu deutsch, zwar anständig, auch ordentlich, soviel steht fest. In Deutschland will jeder aus Tradition zum anständigen Deutschland gehören. Da aber unmöglich alle anständig sein können, gibt es Zulassungsbeschränkungen, hat jeder Zweifel an der Anständigkeit des anderen und insgeheim auch an der eigenen. Und so bekämpfen dann die Anständigen mit der schwarzen Krawatte die mit der rot gepunkteten - die ganz ohne Krawatte zählen ohnehin nicht. Dabei kann ich nur für die krawattenlosen Deutschen schreiben, für alle anderen bin ich eigentlich nicht zuständig. Vor allem sollte man nicht so schwer schreiben, lieber leicht, unkompliziert, locker - das überrascht am meisten. Schafft Verwirrung. Gar nicht erst versuchen, die Literatur zu bereichern. Neue Zweifel. Wieso hat man mich überhaupt eingeladen. Schließlich bin ich kein Schriftsteller. Vielleicht ist das ganze eine Falle. Ich mache Plakate, Montagen - auch zu Deutschland. Warum in einem anderen Metier dilettieren. Auf jeden Fall ist es riskant. Das könnte der Ausweg sein. Jeder wird das verstehen. Ein Schlagzeuger nimmt auch nicht ohne Not an einem Violinwettbewerb teil. Andererseits, warum soll man das Schreiben ganz den Schriftstellern und den Dichtern überlassen. Schließlich sind wir das Volk der Dichter und Denker. Also jeder sein eigener Dichter. Vielleicht kann man es den Schriftstellern einmal zeigen. Möglicherweise ärgert es auch einige. Das wäre immerhin ein Motiv.

Tłumaczenie na język polski:

Od mniej więcej czterech tygodni wyglada to codziennie tak samo: dziś wieczór usiadę sobie i napiszę ów tekst, tak po prostu. Niemcy - tak jakby nie czekało się czterdzieści lat na obrachunek z tym krajem, na spisanie wreszcie wszystkiego czarno na białym, skoro już o tym mowa. Jednak wszelki poczatek niwecza nowe watpliwości. Nie może to być za bardzo patetyczne - bytoby to zbyt niemieckie. Nie sentymentalne - to też niemieckie. Nie heroiczne, nie zawzięte, nade wszystko nie tak doktadne, nie takie matostkowe, nie tak dokumentnie z niemiecka, ale jednak przyzwoite, porzadne, tyle wiadomo na pewno. W Niemczech każdy już tradycyjnie chciałby należeć do przyzwoitych Niemiec. Jako że nie wszyscy jednak moga być przyzwoici, istnieja ograniczenia $w$ tym względzie, każdy wątpi 
w przyzwoitość bliźniego i tym samym także we własna. Tak więc przyzwoici $w$ czarnych krawatach zwalczaja takichze $w$ krawatach $w$ czerwone kropki osobnicy calkowicie bez krawatów w ogóle się nie licza. W dodatku mogę pisać tylko w imieniu ,nieukrawaconych" Niemców, co do innych nie czuję się kompetentny. Przede wszystkim nie należy pisać drętwo, lepiej lekko, nieskomplikowanie, swobodnie - to najbardziej zaskakuje. Stwarza zamęt. Nie należy czynić prób wzbogacania literatury. Nowe wątpliwości. Dlaczego w ogóle zostałem zaproszony, w końcu nie jestem pisarzem. Może to wszystko jest putapka. Robię plakaty, montaże - też na temat Niemiec. Po co chatturzyć w innej branży. Tak czy inaczej to ryzykowne. To mógtby być punkt wyjścia. Każdy to zrozumie. Perkusista też tylko z konieczności uczestniczy w konkursie skrzypcowym. A znów $z$ drugiej strony, dlaczego właściwie mamy pozostawić pisanie catkowicie $w$ rękach pisarzy i poetów. W końcu jesteśmy narodem poetów i myślicieli. A więc każdy dla siebie poeta. A może raz warto pokazać tym pisarzom.! Zapewne kilku to wnerwi. Bytby to zawsze jakiś motyw.

W zgodzie z antropocentryczną teorią języków nie rozpatrujemy powyższego tekstu jako samoistnego bytu, lecz jako rezultat licznych wyborów, których dokonać musiał jego autor, a następnie - tłumacz. Stąd też wynika potrzeba uzupełnienia tekstu o metryczkę, zawierającą nieco informacji o autorze.

Nadawca: autor tekstu Klaus Staeck. ur. 28.02.1938 w Pulsnitz (Połcznica) w powiecie Budziszyn, Kraj związkowy Saksonia. Dorastał w NRD. Niemiecki prawnik, jednak przede wszystkim grafik i karykaturzysta, były prezydent Akademii Sztuk Pięknych w Berlinie; autor plakatów o charakterze politycznym, nazywanych przez krytykę „,satanistycznymi“; sam mówi o sobie, że żywi przekonania socjaldemokratyczne, jest „zakłócającym wygodnictwo krytykiem rzeczywistości“; osoba dużo podróżująca.

Odbiorca: szeroki krąg czytelników w krajach niemieckojęzycznych.

Kontakt między nadawca i odbiorca: duży dystans czasowy i przestrzenny.

Zarys zawartości propozycjonalnej: austriacki wydawca zwraca się do Klausa Staecka z prośbą o napisanie tekstu na temat „Niemcy“, nie określając bliżej jego formy ani ram objętościowych. Tematem zasadniczym jest rozrachunek ze stereotypem Niemca oraz z przeszłością Niemiec, w dość długim okresie - od lat trzydziestych do lat osiemdziesiątych XX wieku. Tematy poboczne to autostereotyp Niemca, obszerny pasaż autobiograficzny, traktujący o dzieciństwie autora w czasie II wojny światowej, o obecnej orientacji politycznej Staecka, o poglądach niektórych niemieckich polityków i o konsekwencjach podziału Niemiec na RFN i NRD.

Rodzaj tekstu: esej

Medium: tekst pisany, przeznaczony do publikacji.

Funkcja tekstu (wg klasyfikacji Karla Bühlera): przedstawiająca i ekspresywna. 
Szczególnie interesuje nas tutaj:

Warstwa stylistyczna: Stwierdzamy dominującą warstwę neutralną z elementami języka potocznego, nasyconego humorem, ale również elementy stylu urzędowego, niektóre fragmenty tekstu nasycone są patosem.

Po zebraniu wstępnych informacji o nadawcy zajmijmy się cechami jego idiolektu (w aspekcie stylistyki), biorąc pod uwagę następujące kryteria:

- konotacja przynależności geograficznej - tekst zawiera liczne galicyzmy (np. Metier, Menu, dilettieren) oraz wyrażenia charakterystyczne dla austriackiej odmiany języka niemieckiego (np. Pimpfenalter);

- konotacja dziedziny, w której pracuje autor (Montagen, Plakate);

- konotacja wartościowania (schamlos - o polityku);

- konotacja frekwencji (Zoil);

- różne cechy składni, wymieńmy choćby kilka: wysoce zróżnicowana długość zdań, mierzona liczbą wyrazów, wahająca się w granicach od 2 do19 wyrazów; odstępstwa od poprawności syntaktycznej, w tym złamanie „żelaznej” zasady składni niemieckiej, nakazującej stawianie verbum finitum na II miejscu w zdaniu (Schafft Verwirrung.); w języku polskim translat Stwarza zamęt nie stanowi odstępstwa od reguł gramatycznych, przez co ten akurat parametr w tłumaczeniu zanika;

- cechy słowotwórstwa: fraza die krawattenlosen Deutschen jest swoistym neologizmem, choć jak najbardziej zgodnym z regułami słowotwórstwa języka niemieckiego: sufiks -los oznacza brak cechy, wyrażonej w poprzedzającym rzeczowniku. Po stronie polskiej tłumaczka zastosowała imiesłów nieukrawaceni Niemcy, który przez redaktora technicznego został ujęty w cudzysłów;

- aliteracja (Schliesslich sind wir das Volk der Dichter und Denker). Po stronie polskiej aliteracja nie pojawia się; tłumaczka musiała dokonać wyboru spomiędzy wyrazów pisarze, poeci, literaci, filozofowie, myśliciele, intelektuali$s c i$, a więc współbrzmienia początkowych spółgłosek nie udało się osiągnąć bez zmiany znaczenia.

Gdybyśmy spróbowali ująć wymienione wyżej cechy tekstu w kategoriach częstości występowania, to moglibyśmy posłużyć się stosowanymi powszechnie $\mathrm{w}$ badaniach kwestionariuszowych określeniami: nie występuje (1) - wystęuje rzadko (2) - wystęuje często (3) - występuje bardzo często (4) - przeważa (5). Przyporządkowanie im wartości liczbowych pozwala na skonstruowanie różnorodnych tabel, pozwalających opisać ekwiwalencję konotatywną jak typ ekwiwalencji A, B, C - lub stosując nawet skalę bardziej zróżnicowaną. Ujęcie już chociażby tylko tych wyżej wymienionych parametrów w ramy ilościowe może stać się przydatnym narzędziem do zastosowania w literaturoznawstwie, do badań stylu autorów i utworów, przede wszystkim do zastosowanie w translatoryce, a także praktycznie $\mathrm{w}$ analizie tłumaczeń, wykonywanych w ramach seminariów licencjackich i magisterskich oraz w ramach studiów podyplomowych dla tłumaczy, a w przyszłości może stanie się inspiracją do stworzenia niemiecko-polskiej kontrastywnej stylistyki. 


\section{Bibliografia}

Adamczyk-Garbowska, M. 1988. Polskie thumaczenia angielskiej literatury dziecięcej. Problemy krytyki przekładu. Wrocław. Zakład Narodowy im. Ossolińskich.

Austin, J.L. 1962. How to do things with words. Cambridge: Harvard University Press.

Austin, J.L. 1972. (thumaczenie na język niemiecki) Zur Theorie der Sprechakte. Stuttgart: Reclam.

Bilczewski, T. 2010. Komparatystyka i interpretacja. Nowoczesne badania porównawcze wobec translatologii. Kraków: Universitas.

Dąmbska-Prokop, U. 2012. O tlumaczeniu dobrze i źle. Kraków: Wydawnictwo Sztuka i Wiedza.

Engel, U. et al. 2000. Deutsch-polnische kontrastive Grammatik. Warszawa: Wydawnictwo Naukowe PWN.

Fleischer, W., Michel, G. i G. Starke. 1993. Stilistik der deutschen Gegenwartssprache. Frankfurt am Main: Peter Lang GmbH.

Gajda, S. 2008. „Stylistyka funkcjonalna, stylistyka pragmatyczna, stylistyka kognitywna”. W: Ostaszewska, D. i R. Cudak (redakcja naukowa). Polska genologia lingwistyczna. Warszawa: Wydawnictwo Naukowe PWN. 143-149.

Kisiel, M. 1991. „Polskie przekłady Requiem Anny Achmatowej. Uwagi wstępne”. W zbiorze: Fast, P. (red.). Przeklad artystyczny. Tom 2. Zagadnienie serii translatorskich. Katowice: Wydawnictwo Uniwersytetu Śląskiego. 31-42.

Koller, W. 1992. Einführung in die Übersetzungswissenschaft. Heidelberg-Wiesbaden: Quelle und Meyer.

Krysztofiak, M. 1998. „Wprowadzenie do analizy przekładów baśni braci Grimm”. W zbiorze: Fast, P. (red.). Przekład artystyczny a wspótczesne teorie translatologiczne: studia o przekładzie. Katowice: Wydawnictwo Śląsk. 165-175.

Krysztofiak, M. 2011. Translatologiczna teoria i pragmatyka przekładu artystycznego. Poznań: Wydawnictwo Naukowe UAM.

Kubaszczyk, J. 2016. Faktura oryginału i przekładu. O przekladzie tekstów literackich. Warszawa: Wydawnictwo Naukowe PWN.

Legeżyńska, A. 1999. Ttumacz i jego kompetencje autorskie. Warszawa: Wydawnictwo Naukowe PWN. Musialik, B. 1991. „Aspekt językowy i stylistyczny polskich przekładów poezji Belli Achmaduliny”. W: Fast, P. (red.). Przektad artystyczny. Tom 2. Zagadnienie serii translatorskich. Katowice: Wydawnictwo Uniwersytetu Śląskiego. 118-130.

Nordmann, M. 1993. „Rhythmus im Fachtext”. W: Schröder, H. (red.). Fachtextpragmatik. Tübingen: Gunter Narr Verlag. 291-306.

Osadnik, W.M. 2010. Teoria wielosystemowa i rodzaje ekwiwalencji w przekladzie. Katowice: Wydawnictwo Śląsk.

Paszek, J. i G. Wilk. 1991. „Incipit Eugeniusza Oniegina po polsku (Szkic komparatystyczno-ludyczny)". W: Fast, P. (red.). Przeklad artystyczny. Tom 2. Zagadnienie serii translatorskich. Katowice: Wydawnictwo Uniwersytetu Śląskiego. 17-30.

Pisarkowa, K. 1998. Pragmatyka przekładu. Przypadki poetyckie. Kraków: Wydawnictwo Instytutu Języka Polskiego Polskiej Akademii Nauk.

Płusa, P. 2007. Rozwijanie kompetencji przektadu i ksztatcenie tlumaczy. Katowice: Wydawnictwo Uniwersytetu Śląskiego.

Prokop, I. 2011. „Archaismen in deutsch-polnischer Translation”. W: Badstübner-Kizik, C. (red.). Linguistik anwenden. Frankfurt am Main: Peter Lang. 23-40.

Prokop, I. 2016. Pragmalingwistyka antropocentryczna. Poznań: Wydawnictwo Naukowe UAM.

Sanders, W. 1977. Linguistische Stilistik. Göttingen: Vandenhoeck und Ruprecht.

Sandig, B. 1978. Stilistik. Sprachpragmatische Grundlegung der Stilbeschreibung. Berlin/New York: Walter de Gruyter. 
Searle, J. 1969. Speech acts: an essay in the philosophy of language. Cambridge: Cambridge University Press.

Searle, J. 1971. Sprechakte. Ein sprachphilosophischer Essay. Frankfurt am Main: Surkamp. Ins Deutsche übersetzt von Rolf Wiggershaus.

Skubalanka, T. 2001. Podstawy analizy stylistycznej. Rozważania o metodzie. Lublin: Wydawnictwo UMCS.

Tabakowska, E. 1999. O przekladzie na przykładzie: rozprawa tlumacza z „Europa” Normana Daviesa. Kraków: ZNAK.

Wiertlewski, S. 1995. Pytania bez odpowiedzi: pytania jako pośrednie akty mowy. Poznań: Sorus.

Zarek, J. 1991. „Seria jako zbiór thumaczeń”. W: Fast, P. (red.). Przekład artystyczny. Tom 2. Zagadnienie serii translatorskich. Katowice: Wydawnictwo Uniwersytetu Śląskiego. 7-16.

Zdankiewicz-Jedynak, D. 2008. Wyklady ze stylistyki. Warszawa: Wydawnictwo Naukowe PWN.

Żydek-Bednarczuk, U. 2005. Wprowadzenie do lingwistycznej analizy tekstu. Kraków: Universitas.

\section{Analizowany fragment tekstu}

Staeck, K. 1979. „Jeder zweite Deutsche hat Übergewicht“. W: Deutschland, Deutschland. 47 Schriftsteller aus der BRD und der DDR schreiben über ihr eigenes Land. Salzburg und Wien: Residenz-Verlag. 259-266.

Tłumaczenie polskie: Prokop, I. 1993. „Co drugi Niemiec ma nadwagę”. W zbiorze: Karolak, Cz. (red.). Niemcy o sobie. Naród - państwo - charakter narodowy w oczach intelektualistów niemieckich. Poznań: Instytut Zachodni. 181-186. 